UDC 1(091)

\author{
EBO SOCRATES, \\ Doctor of Social \& Political Philosophy, \\ Institute of Foundation Studies \\ Federal University Otuoke, Bayelsa State, Nigeria
}

\title{
RESTORING THE AFRICAN ORIGINS OF PHILOSOPHY
}

The standard bias is that philosophy originated in Miletus, in the Greek province of lonia in Asia Minor. The bias also upholds Thales, a citizen of Miletus to be the first human ever to engage in formal philosophy. The creed of the bias is that the blessings of philosophy spread to the rest of the world from this salvific Greek city. The world owe it to the ingenuity of the Greeks, the appearance of philosophy and science as formal enterprises of learning. This is the "truth", at least according to mainstream Western literature. Abundance of documentary evidence stating otherwise did not matter. It did not matter also that Thales himself travelled to Egypt and spent many years there, studying philosophy. It did not matter also, that Thales merely reechoed in lonia, the teachings he received from the school he attended in Egypt. But facts are sacred; biases are optional. Philosophy, indeed had been formally taught in Egypt for thousands of years before Thales ever travelled to Egypt. Literature abounds to that effect. However, the Greeks played a pivotal role in the spread of philosophy to the rest of Europe. The Greeks were the first European nation to philosophize. But that did not amount to the origin of philosophy. It was an epoch in the spread and popularization of philosophy. The fall of Egypt to the invading armies of Alexander the Great, the edits of emperors Theodosius and Justinian of the Roman empire, the invasion of Islam, the slave trade, the experience of colonialism and the subsequent racism changed all that. Africa came to be denigrated as the "Dark Continent", and as such was deemed incapable of culture and intellectual advancement. This bias significantly influenced, and has arguably continued to colour Western discourse on African themes, covertly and overtly. African intellectuals and researchers all over the world, owe it to posterity, the duty to render the truth about the origins of philosophy. This research relies solely on library research in unearthing oft neglected classical documents that point abundantly to the African origin of philosophy.

Key words: African Philosophy; Egypt; Seba; Thoth; Waset; Ancient Philosophy; Ionia; Miletus; Thales; Pythagoras; Aristotle.

\section{Introduction}

Although every human person who is of the age of reason is a potential philosopher, not all reasonable persons are philosophers. Yet, there is no human person who does not lead his life according to one philosophy or the other. It can be in the form of commonsensical maxims, an ideology, cultural or religious beliefs. Human beings necessarily have to make a rationally purposeful interpretation of their existence in other to give meaning to their lives. There necessarily has to be a rational way of meandering through the maze of challenges typically posed by existence. Ipso facto, no people on earth can be denied of the heritage of an indigenous philosophy of some sort. The ability to reflect over realities is ontological to man. Philosophy reflects man's persistent attempts at rationally confronting his existence; to make the cosmos intelligible; to make his existence in the world meaningful. The entire human race has been engaged in this enterprise in their autochthonous localities.

However, as a radical formal enterprise, subject principally to the dictates of reason; as a body of tradition of established questions and answers, philosophy originated in Egypt, with influences from Ethiopia [Herodotus, 450 BC; Diodorus, 50 BC; Asante, 2004; Ayo, 2011]. Although this assertion runs counter to the ordained narrative of the philosophy establishment, it however remains the iconoclastic fact. Even the early Greek philosophers never claimed for themselves, the origin of philosophy. They copiously acknowledged the Egyptian origins of their ideas. In fact, they took pride in acknowledging that [Diodorus, $50 \mathrm{BC}$ ]. It was not until the nineteenth century that the narrative started changing [Asante, 2004]. During this time, racial differences between Black Africa and Europe were expressed socially through the political subjugation of Africa by Europe.

Western Europe needed to justify the inhuman treatments meted out to African people who had been enslaved in Europe. The slaves were often regarded as beasts of burdens by their owners. European conscience would be greatly eased if Africans were painted as a subhuman people. That would justify the bestial treatments that were given to African slaves by Western slave owners. A subhuman people couldn't have been capable of such mental advancement as philosophy, hence the conspiracy by modern era Western authors to suppress the evidence of the African origin of philosophy and to promote the so called apishness of the African intellect [Nantambu, 2004]. Therein, lies the origin of the distortions in the history of 
ancient philosophy. In European histories of philosophy, the Egyptian era which spans thousands of years is completely obliterated. Philosophy begins with Thales, ushering in the Greek era. Many European authors unashamedly declare Thales, the father of philosophy despite abundant documentary evidence that Thales was schooled in Egypt; despite abundant surviving evidence to the contrary. It is all about advancing their narrative about the Black race: a backward people who are incapable of anything sublime [Abdatista, 2011].

The reality of colonialism advanced the narrative further. Colonized African states received European education system. This bias was indoctrinated in generations of African philosophers so successfully that scholars of African origin promote these biases as the standard truth in their philosophical writings. But facts are sacred. The evidences of the African origins of philosophy are ubiquitous in history. Like pregnancy, it cannot be successfully hidden.

\section{The Birthplace of Philosophy}

Although it has been stated adequately above that philosophy is as old as the rational man, and as such is a universal heritage. Philosophy as an organized, formal enterprise however, was first recorded in Egypt. Philosophy was birthed around 3000 BC in the mystery schools of ancient Egypt. These were the first ever higher institutions of learning where students were stringently trained in character and learning. The oldest and most prominent recorded philosopher of this era was Thoth, who was later known in history as Thoth Hermes [Holley, n.d]. In the mystery schools of Egypt, philosophy flourished and was formally imparted on the students who flocked to these schools from all over the known world. It was indeed, a stringent program of the discipline of the mind and the body. The students were required to subject their bodies and emotions to discipline, as preparation for the disciplining of the mind that will be required by philosophy and the subsequent enlightenment that will result from the knowledge of philosophy.

Among the celebrated philosophers of ancient Egypt were Amenhotep 2700BC, Imhotep 2700BC and Ptahhotep 2500BC. Others were Amenemhat, Merikare, Duauf, and Akhenaten. Ptahhotep was a celebrated moral philosopher. His philosophy survived to this day in his book known as the Maxims of Ptahhotep [Bowder, 1988]. In the Ptolemaic era of the Greek occupation of Egypt, another prominent philosopher, Manetho emerged. Manetho, a thorough bred philosophy scholar was ordered by Ptolemy I Soter to write a history of Egyptian philosophy [James, 1954]. Thus, Manetho became the primary source of Egyptian philosophy to the hordes of Greeks who trooped to Egypt after the Alexandrian conquest in order to be schooled in philosophy.

Unlike Thales who had no actual books attributed to him or any of his followers (because he had no original ideas of his own in philosophy or science), Thoth had books actually attributed to him. While Clement of Alexandra claimed that Thoth authored 42 books, Manetho wrote that Thoth authored 36,526 books [Jasnow and Zauzich, 2005]. It is clear that Thoth could not have personally authored such large volumes of books. It is clearly evident that his teachings were so vast and so influential that his disciples continued to develop them and attribute them to his name. Some Western authors erroneously designate Thoth as a god in the sense of non-human. The object of the Mystery religion was the divinification of man. Jesus, an initiate and adept of the Mysteries who achieved the Christ consciousness also achieved divinification, and is to this day revered as divinity.

Early Greek Interactions with Egyptian Culture

Egyptians of antiquity had stern concerns about plagiarism regarding the Greeks. They distrusted the Greeks and imposed strict immigration restrictions against them. In fact, it was a capital offence for a Greek to enter Egypt without due immigration authorizations [James, 1954]. Pythagoras had to obtain a letter of introduction from Polycrates, addressed to King Amasis of Egypt before he could be allowed to enter Egypt. Amasis granted Pythagoras the permission to enter Egypt and gave authorizations to Mystery schools to teach him [NNDB, 2014]. Pythagoras would eventually spend a total of twentytwo years in Egypt, studying philosophy and the sciences at multiple schools. Thales who advised Pythagoras to travel to Egypt for further education was himself educated in Egypt [Dosidorus, 50 BC; James, 1954].

The friendship between Amasis and Polycrates led to relaxation of the immigration rules. Greeks were eventually allowed to enter Egypt and settle at Naucratis as they were not granted access to the hinterland [Herodotus 2.154; James. 1954; Dunn, n.d]. During the Egypt-Persian war, lots of Greeks were recruited into the Egyptian army as mercenaries, thus opening further avenues of interactions between the Greek and the Egyptians. As the Greeks settled in Egypt, they immersed themselves in the study of Egyptian culture which traditionally had always been a source of fascination to them.

An important phase in early Greek interaction with the Egyptian culture was the colonization of Ionia by Egypt [Roebuck, 1960]. This colonial contact with Egypt was practically what gave birth to the philosophic culture and openness to new ideas in lonia unlike other Greek regions. The Egyptian colonizers built Mystery temples which were centers of worship, learning and dissemination of philosophy. It was against that backdrop that the lonians received the enablement to become the first among the Greeks to embark upon the philosophic enterprise. Early Greek philosophers from Thales, Anaximander, and Anaximenes through Heraclitus down to Pythagoras were lonians. Even Democritus was an Ionian.

Philosophy flourished in lonia not because of its seaports as touted in Western literature [Stumpf, 1994], but because it was brought there by Egyptians who colonized lonia. Athens was equally a seaport. Philosophy did not flourish in Athens but was ruthlessly crushed when it was brought there much later. There were numerous seaport cities that did not philosophize. The critical difference with regards to lonia was the presence of Egyptians who practiced in the province they colonized, the philosophy they learnt back home in Egypt.

Beyond the Greek islands, the influence of Egypt was felt in much of what is known today as Middle East and beyond [James, 1954]. Egyptian colonial influences at different times spanned these areas. Such was also the spread of Egyptian Mystery temples and their teachings. The Judaic religion is an offshoot of Egyptian mysteries as Moses was not only schooled in Egyptian mysteries, he rose to the prestigious rank of a teacher [Jochannan, 1974].

The Influence of the University of Waset (Thebes, now Luxor)

Contrary to the bias of mainstream Western literature, Plato's Academy was not the first higher institution of learning in history. The Temple of Waset had served as a higher institution of learning for over one thousand, four 
hundred years before Plato graduated from it to establish his own school in his native Athens in $387 \mathrm{BC}$. The Temple was of Waset built by the philosopher-King, Amenhotep III who ruled ancient Egypt, then known as Kemet from 1405 - 1370 BC. Waset was a center learning in philosophy and the sciences. Generations of Greek philosophers and scientists were trained in Waset. According to Clement of Alexandria, if a book of a thousand pages were to be written, it would not be enough to contain the names of all the Greeks who passed through Waset [Obenga, 1995].

Plato's Academy was founded at Akademia in Athens. Instead of talking of academics we ought to be talking of wasetics for Waset had played host to the higher education endeavor for over a thousand years before Akademia played that role. Calling the higher learning endeavor academic life rather than wasetic life is one the deliberate misrepresentations of history by the West against Africa. Among the illustrious Greeks trained at Waset are:

Thales as well as Anaximander his pupil went to Waset. Pythagoras spent 22 years at Waset. Socrates spent 15 years. Plato spent 11 years at Waset. Aristotle spent 13 years. Hippocrates spent 20 years at Waset. Euclid spent 11 years. Solon was trained at Waset. So were Diodorus, Euripides and Archimedes. Clement of Alexandria testified that learning at Waset was so prestigious among the Greeks that even those who never matriculated at Waset claimed to have attended the school [Obenga, 1995; Dosidurus, 54 BC; James, 1954; Diogenes, c 337 BC; Clement, c 100 BC].

In the light of this, the crop of scholars in ancient Greece whom Western literature refer to as the founders of philosophy and science were actually alumni of ancient Egyptian University of Waset.

The beginning of the Greek Plagiarism of Egyptian Philosophy

The entire gamut of what is described in Western literature as "Ancient Greek Philosophy" is nothing but plagiarized Egyptian philosophy. From Thales down to Aristotle, all merely reproduced in Greek language, the philosophy they copied from Egypt. Thales admittedly travelled to Egypt to be schooled in philosophy. Diogenes Laertius wrote that Thales learnt astronomy and mathematics from his tutors in Egypt. When Thales said that everything came from water. It was a novel idea to the Greeks but commonplace knowledge among the Egyptians. Thales couldn't have completed his education at Waset without a comprehensive lesson on the Enneads [James, 1954].

Nun was the transcendent primordial water from which all things came. Every existent on earth was differentiated from Nun by Atum, the God of gods [Frankfort, 1948]. Thales was not the first to copy it. This plagiarism is also evident in the Pentateuch, sacred scriptures of the Hebrew religion which has its origins in Egyptian Mysteries. In the creation account of Genesis, the primordial water is uncreated, rather, all things are differentiated from it [James, 1954; Jochannan, 1974].

Thales after teaching Anaximander realized that he may not have had enough knowledge of philosophy to sufficiently equip Anaximander in philosophy. He advised Anaximander to travel to Egypt to be educated by the masters themselves in order to upgrade his knowledge of philosophy [Zeller, 1955]. Indeed, Anaximander on return from Egypt did make improvements on the philosophy of Thales.

Anaximander posited the boundless as the source of all things. This idea is neither original to Anaximander nor to the Greeks as a people. The boundless is the formless matter out of which Atum, the Demiurge formed all things [James, 1954; Zeller, 1955]. Anaximander thus demonstrated that he had a deeper understanding the cosmogony of Atum. Thales stopped at Nun, the primordial water. Anaximander went beyond the Nun to talk about formless matter. Anaximenes would go beyond the boundless to talk about air which represented the spirit, as the source of all things. All these teachings were aspects of the creation teachings of the Egyptian philosophy which the Greek copied.

The idea of the boundless which is the same as chaotic matter or formless matter is evident in Genesis (ch.1). The Pentateuch which consists of Genesis, Exodos, Numbers and Deuteronomy was written c. 800 BC, a period that clearly predates Ionian philosophy which birthed around 500 BC. The Pentateuch is ascribed to Moses. Moses himself according to Philo was an Egyptian priest and hierogrammat. He was thoroughly schooled in Egyptian Mystery system as he was an adopted son of Pharaoh's daughter. Even, Israel as a nation migrated from Egypt. Moses flourished around $1100 \mathrm{BC}$, a period the Greek nation was not in existence. The ideas expressed by Anaximander and Anaximenes clearly existed before the Greek era. They could not have been the authors of these ideas. The teachings are found in Memphite Theology which dates back to 4000 BC [James, 1954].

Heraclitus' ideas of Fire and Logos are traceable to the Egyptians who worshiped the God of Fire. The Greek word "pyramid" has its root as "pyr" which means "fire". Egyptians clearly dedicated the pyramids to the God of Fire. The pyramids era dates back to $3000 \mathrm{BC}$, a period that clearly predates the lonians. Even the Genesis portrays God breathing air into man to make life possible. Anaximenes couldn't have claimed authorship of the idea of air as a source of being. It is abundantly clear that what passed for Ionian philosophy were repetitions of the teachings learnt by Greeks who travelled to Egypt to be educated [Diodorus, $50 \mathrm{BC}$ ].

\section{The Meaning of Philosophy}

One of the standard biases of Western accounts of the history of philosophy is that Pythagoras invented the theory of the square of hypotenuses, and that Pythagoras coined the word "philosophy". Pythagoras spent 22 years studying at various schools in Egypt. Polycrates gave him a letter of introduction to Amasis who granted him leave to enter and study in Egypt [James, 1954; Zeller, 1955]. When Pythagoras got to Egypt. He met people studying philosophy. $\mathrm{He}$ attended schools where philosophy was taught. Those schools had teachers and students. Does it mean that the teachers did not have a name for what they taught; what they have taught for thousands of years for that matter? Did the students not have a name for what they learnt? It certainly would have been absurd if that were the case. It wasn't.

The term "philosophy" has its root in the Ndu Ntr word "seba". Ndu Ntr was the ancient Egyptian language. "Seba" in Ndu Ntr means "the wise". It also connoted "lover of wisdom". "Seba" was transliterated into Coptic, a later Egyptian language as "sebos" and subsequently into Greek as "sophia". Within Egypt, "seba" was "the wisdom". The oldest written evidence of the word "seba" appears on the tomb of Antef I which dates to 2052 BC [Asante, 2004]. Outside Egypt, it was known as "the wisdom of Egypt". Those who went to Egypt to acquire "seba" went to acquire "the wisdom of Egypt". They loved "the wisdom of Egypt". Pythagoras was among those who loved "the wisdom of 
Egypt". As stated earlier, he spent 22 years studying this body of knowledge known as "the wisdom of Egypt".

When Pythagoras returned to his native Samos with this "wisdom of Egypt" he met stiff opposition because the "wisdom of Egypt" was foreign to the Greeks. Unlike Egypt where it was the highest expression of culture, it was a sort of counter-culture to the Greeks. Naturally, the Greeks became hostile to it and Pythagoras had to leave Samos for Crotone in southern Italy, where he established his own school and gained significant influence. The influence was short-lived though, as the Greeks always distrustful of the foreign "Wisdom of Egypt", rose against his influence and killed him [BBC, 2014]. Nonetheless, like Pythagoras some other Greeks fell in love with "the wisdom of Egypt". Like Pythagoras, they were all loved "the wisdom of Egypt" which the Greeks transliterated as "sophia". They were called "lovers of the wisdom of Egypt. The activity they engaged in became known as "the love of the wisdom of Egypt" - philos sophia - love of wisdom (of Egypt).

It is incorrect to attribute the origin of the term "philosophy' to Pythagoras. The key word is the term, "sophia" which in its Ndu Nri roots, "seba", connoted "lover of wisdom". As a matter of fact philosophy had been known by literally the same term but in different language for over 2500 years in Egypt before Pythagoras was born. As stated earlier on, as far back as 2052 BC, "seba" which is the root word as well as the original term for "philosopher" had been inscribed on the tomb of Antef I. Like in 2052 BC, "philosopher" has always meant the same thing - a professional in the body of knowledge and enterprise of systematic questions and answers which originated in Egypt. It was basically known as wisdom, not commonsensical wisdom but that system of wisdom which has its roots in ancient Egypt. It is noteworthy that the Pidgin word for wisdom is "sabi" which also bears close resemblance to the Egyptian "seba' which also means wisdom. Certainly, the words "Seba", "sebos", "sophia" and "sabi" are related. They all mean wisdom. The similarities couldn't have been mere coincidences. They have a common root - seba.

Even the theorem of the square of hypotenuses which has been erroneously christened Pythagoras theorem by Western literature had been in use in Egypt for thousands of years before Pythagoras ever travelled to Egypt. Egyptians used the theorem in the construction of pyramids. The pyramid era was around $3300 \mathrm{BC}$. Like philosophy, it was among the things Pythagoras learnt in his twenty-three years sojourn in Egypt. He couldn't have authored it. In fact, Plutarch, Demetrius and Antisthenes wrote that Pythagoras offered sacrifices to the gods before he was shown the proof of the theory of square of hypotenuses [James, 1954]. Diodorus Siculus (50 BC) clearly wrote that Pythagoras learnt all he knew in philosophy and mathematics from Egypt. Pliny (N. H., 36, 9), Diogenes (VIII 3), Herodotus (Bk. II 124) and Antipho all concurred that Pythagoras learnt all he knew in philosophy, medicine and mathematics from Egypt. He did indeed pay handsomely for the knowledge he got. Pythagoras gave a silver goblet each to the priests of Heliopolis, Memphis and Thebes [James, 1954].

Suffice it to say that while philosophy was new to many Greeks at the time of Pythagoras, it was not new to the entire world. Pythagoras was a hardworking student who diligently learnt all he could from Egypt and brought the knowledge home to impart it to his own people. His philosophy and mathematics were not original but were novel to the Greeks.

\section{The Decline of philosophy in Egypt}

Six events led to decline and final extinction of philosophy in Egypt. The first was the successful invasion and conquest of Egypt by Alexander the Great. The second was the massive looting of the royal libraries by the Greeks. The third was the edit of Emperor Justinian in the 4th century. The fourth was the edit of Emperor Theodosius in the 6th century. The fifth was the success of Christianity. The sixth and the final nail in the coffin was the Islamic conquest of Egypt.

Alexander's Invasion of Egypt and the Looting of Royal Libraries

The Greeks under the command of Alexander the Great successfully invaded and conquered Egypt in $332 \mathrm{BC}$. The invasion was the watershed of the decline of philosophy in Egypt as well the theft of Egypt's philosophic legacy by the Greeks. The conquest of Egypt by Alexander put a stop to the long history of culturally rich leadership that has nurtured philosophy among the people for four thousand, seven hundred years [Diodorus, $54 \mathrm{BC}$ ]. Prior to his conquest of Egypt, Alexander always had a keen interest in philosophy. He was tutored by Aristotle. At a point in time he gave Aristotle a huge sum of money to procure book, which then were not easily in circulation. The conquest of Egypt granted the Greeks unfettered access to Egyptian culture and literature.

Although, Western history is silent on that, it is a fact that Aristotle accompanied Alexander to Egypt and looted a great deal of books from the royal libraries [Natambu, 2001; James, 1954]. These books represented thousands of generations of Egyptian philosophical heritage. These treasure troves were taken to Greece where they were rendered as Greek heritage.

Greek military commanders known as Ptolemies who administered Egypt built a university at Alexandria were they got Egyptian scholars to train Greek nationals in philosophy. Ptolemy I Soter (323-283 BC) compelled Manetho to write a comprehensive history of Egyptian philosophy which was translated into Greek for use by Greek students at Alexandria and beyond [James, 1954].

The Edits of Emperors Justinian and Theodosius

The Roman Empire conquered Egypt in $30 \mathrm{BC}$. Rome tried to impose the Roman way of life all over her domain. However, Egypt represented a problem. Egypt had a highly organized religioos and cultural system with temples and adherents across the empire. The Roman leadership was worried about having to cope with divided ideologies and the apparent intellectual superiority of the Egyptians. Constantine had made Christianity the state religion in 313 AD. From the fourth century onwards, Christianity was the officially the religion of the Roman Empire. To suppress the influence of the Egyptian Mysteries, which equally embodied the Egyptian philosophical heritage, Emperor Justinian outlawed the Mysteries throughout the Roman Empire. The edit led to the closure of Egyptian Mystery temples which equally served as philosophy schools throughout the empire.

However, the Mysteries thrived in Egypt among the aborigines in the hinterlands on the banks of the Nile. In the sixth century however, Emperor Theodosius became so passionate at exterminating the Egyptian Mystery that he hunted down its priests and adherents, burning all their literatures and pulling down their temples. He succeeded so exceedingly well that he hunted the Mystery priests down to the last priest and exterminated him, effectively putting to an end, the Egyptian Mystery system as there were no further priests left to carry on with the necessary transfer of knowledge [James, 1954]. 
The Political Success of Christianity over Egyptian Mysteries

Christianity as well as Judaism has its origin in the Egyptian Mystery system. Jesus, like Moses before him was schooled in the Egyptian Mystery system. Jesus attended the Mysteries lodge at Mount Carmel [James, 1954]. Even the Bible account says that Jesus grew up in Egypt (Mathew 1:14-15). Jesus is said to have fled to Alexandria with his teacher Jehoshua when King Janneus ordered the killing of initiates [Pratt, 2001]. History abundantly confirms that Jesus received his final initiation into the Egyptian Mystery system at the Pyramid of Cheops [Weor, 1956]. In all ramifications, Jesus was an initiated adept of the Mysteries.

In doctrinal content, some scholars argue that there is nothing unique or original about Christianity. Christianity is apparently a synthesis of the Egyptian Mysteries and the Jewish experience. The concept of Christ for instance is original to the Mysteries, and not Christianity. The Chrestos was used to designate would be initiates on probation. At the completion of their training and upon initiation, they were designated as Christos - Christ [Pratt, 2001]. Jesus was a Christ among the numerous Christs of the Mysteries. The influence of Pythagoreanism, which in turn is a branch of the Mysteries is writ large in the teachings of Christianity. The teachings Essenes of which Jesus was a prominent member are all evident in Christianity.

A serious challenge was posed to Christianity by the Mysteries. Christianity claims to be the truth while it designates other religions as pagan. But a close look at Christianity easily shows that it is an imitation of the Mysteries [James, 1954]. The Mysteries were clearly superior to Christianity in richness of thought and history. Which enlightened man would forgo the original for an imitation? Thus, the Mysteries continued to flourish and were considered superior to Christianity. Christianity achieved a political masterstroke when its headquarters was moved from Jerusalem to Rome, effectively making it the Church of Rome. This move excited the interest of the Roman leadership. At last, Rome has got its own catholic religion. The Egypt centeredness of the Mysteries presented political discomfitures to Rome.

Christianity leveraged on its status as the state religion of the Roman Empire to push for the crushing of its perpetual rival, the Mysteries. In so doing, the philosophic heritage of the Egypt was brutally crushed by the state and replaced with Christianity [James, 1954]. Even a portion of the New Testament urges people to beware of philosophers (Colossians 2:8). Christianity has a long history of violently crushing rival ideologies from the crusades to the inquisitions. The violent replacement of the Mysteries with Christianity was the coup de grace of Egyptian philosophy; it put the final nail on its coffin.

\section{The Islamic Conquest of Egypt}

Whatever survived the onslaught of Christianity in the Egyptian philosophic heritage was put away permanently by the Mohammedan conquest of Egypt. Egypt became subject to a different civilization entirely. The Islamic conquest brought about an influx of Arabs into Egypt that is so massive that the indigenous Black people of Egypt are but today a tiny minority. The aborigines fled southwards to Sudan and Ethiopia away from the invaders. What obtains in Egypt from the seventh century till date is the Islamic civilization. The influence of Arabs are so pervasive in Egypt that today, for all practical purposes, Egypt is more or less an Arab nation.

Unlike the Mysteries, Islam is a closed religion. It has no provision for free thought. It is fundamentally a dogmatic religion. The price of dissent in Islam is death. It was indeed an antithesis to the culture that nurtured the Mysteries. Islam changed Egypt from a proud nation that is the source of civilization and universal religion to a culturally subject nation that looks up to Saudi Arabia for cultural, religious and political guidance. Pathetic. Egypt today politically and ideologically identifies as an Arab nation. The aborigines suffer severe discriminations from the Arab majority who arrogantly consider themselves superior. Pathetic. The Mysteries are gone. The great Egyptian philosophic civilization is gone.

The Deft of Egyptian Philosophic Heritage by Aristotle

Aristotle was the greatest plagiarist of all times. He took intellectual plagiarism to a sacred height. Aristotle was the tutor of Alexander the Great. Even before his conquest of Egypt, Alexander had given Aristotle large sums of money to purchase books, which by the way were not really so much in circulation then [James, 1954]. Books were among the prized booties Alexander looted from Egypt. Aristotle did visit Egypt in the company of Alexander and carted away books from the royal libraries to Greece. That was how Aristotle got attributed to himself, incredible volumes of books in so many fields that it is impossible to be authored by one man. Aristotle practically stole the credit for the works of thousands of men over thousands of years in Egypt.

It is argued that Aristotle did not make any significant impute on what he pirated from Egypt [James, 1954]. The fact that his school never made any advancement on the doctrines contained in the books after his death points to their foreign origin. Philosophy in the Greek world never went beyond the level it attained at the time of Aristotle. It was a foreign culture which the Greeks of that era neither really understood nor owned.

\section{The Error of "African" Philosophy}

African scholars of the early twentieth century bowed to the bias of "Western" philosophy by Europeans who perpetuated the plagiarism and theft of the Egyptian legacy. The truth is that there is no such thing as "Western Philosophy" for what is claimed as Western philosophy is actually African philosophy. It is a philosophy developed in Africa and propagated from Africa to the entire world. The acceptance of that false paradigm by twentieth century African philosophers was erroneous. Ethno-philosophy was projected as "African Philosophy", ignorantly surrendering the true African origin and the Africanness of philosophy to the West.

There is no gainsaying that the Western world has made great contributions to philosophy. These contributions however started from the modern era. From the ancient period to the medieval period, philosophy was purely an African heritage which the Greek copied and rendered as best as they could. The West never manifested originality in philosophic thought until the modern era. In the middle ages, philosophic thought was entirely frozen. Darkness loomed over the intellectual world as Christian theology took the place of philosophy. As stated earlier on, it was also in the early medieval era that the Egyptian Mystery schools/temples were eradicated by the powers that be.

\section{Conclusion and Recommendations}

History shows with full force of intellectual clarity that "Western philosophy" is actually African philosophy. Contrary to the mainstream narratives, philosophy as a system of inquiry, and as an organized body of knowledge did indeed originate in Egypt; and not in Greece. There 
was a theft of credit on the part of the West. It is possible that the deliberate disregard of history by the Western historians of philosophy who promoted the Western origin narrative was inspired by racism. The political defeats suffered by Africa, the experience of slavery, colonialism and the denigration of blackness put Africa on a rung so low in the ladder of worthiness in the West. Africa was generally regarded as the "Dark Continent". It is embarrassingly humbling to Western pride to be reminded by history that the intellectual light actually came from the so called "Dark Continent". Glaringly abundant historical evidence notwithstanding, the West attributed to the Greeks, the origin of philosophy.

There is a need for the re-education of African students of philosophy. Beyond that, it is time to expunge the outright lies and misrepresentations of history in philosophy books used in teaching students, the world over. Why would the lie "Thales is the father of philosophy" continue to be perpetuated when history abundantly makes it clear that Thales not only travelled to Egypt to be educated in philosophy, also strongly advised his pupil, Anaximander and Pythagoras to do same [James, 1954]. Philosophy as an iconoclastic enterprise ought to be a universal respecter of truth. When would scholars gladly pronounce Thoth as the father of philosophy? When would Waset be celebrated as the first center ever, of higher learning? It is time to restore the African origins of philosophy and science.

\section{REFERENCES}

Abdatista, G. 2011. The Philosophy of Colonialism: Civilization, Christianity, and Commerce. Available at: https:// scholarblogs.emory.edu/violenceinafrica/sample-page/thephilosophy-of-colonialism-civilization-christianity-and-commerce/ (Accessed: 25.09.18)

Alexander, B.D. 1922. History of Philosophy. Glasgow.

Asante, M. K. 2004. An African Origin of Philosophy: Myth or Reality? Available at: http://www.asante.net/articles/26/ afrocentricity/ (Accessed: 11.09.18)

Aucher, J. 1826. Philo

Ayo. 2011. The origins of the Ethiopian state. African House of Rastas. Available at: https://www.africaresource.com/rasta/ sesostris-the-great-the-egyptian-hercules/the-origins-of-t heethiopian-state-by-prof-ayo/ (Accessed: 08.09.18)

BBC. 2014. Available at: http://www.bbc.co.uk/history/ historic_figures/pythagoras.shtml (Accessed: 08.09.18)

Bowder, A. 1988. Nile Valley Contributions to Civilization. Karmaic Institute.

Besant, A. 1901 Esoteric Christianity. Quest Books; 2nd edition (January 1, 2006), 302 p.

Flavio Josefo. Obras completas de Flavio Josefo, en 5 volúmenes traducidos del griego al español por Luis Farré. (Buenos Aires: Acervo Cultural / Editores, 1961.) Vol. 5: Contra Apión. Available at: https://elmundobiblicodigital.files.wordpress.com/2013/12/contra-apic3b3n-sobre-la-antiguedaddel-pueblo-judc3ado-por-flavio-josefo.pdf

Daniel, R., McBride, \& Berkley. (Eds). 2003. The Oxford Essential Guide to Egyptian Mythology. Publisher: Berkley, 432 p.

Diogenes, L. (c. 366 BC). Lives of Eminent Philosophers.

Diop C. A. 1974. The African Origin of Civilization, Myth or Reality? L. Hill, New York: $336 \mathrm{p}$.

Dunn, J. (n.d). Amasis, the Last Great Egyptian Pharaoh. Available at: http://www.touregypt.net/featurestories/amasis.htm (Accessed: 01.09.2018)

Frankfot, H. 1948. Ancient Egyptian Religion. New York: Harper and Row, Harper torchbooks, 172 pages

Hasting. (1898-1904). Bible Dictionary, Publoshed, 1963, NY: C. Scribner's Sons (5 vols).

Hastings, J. 1908. Encyclopedia of Religion and Ethics. Available at: https://archive.org/details/encyclopaediaofr01hastuoft/page/n9 (Accessed: 09.09.2018)
Herodotus. (450 BC). Histories. Available at: http:// classics.mit.edu/Herodotus/history.html (Accessed: 01.09.2018) Jasnow, R. L. \& Zauzich, K.T. 2005. The Ancient Egyptian Book of Thoth: A Demotic Discourse on Knowledge \& Pendant to Classical Hermetica. Otto Harrassowitz Verlag. 678 p.

Jochannan, Y. 1974. The Black Man's Religion. In: Vol.2 The Mith of Genesis is Exodus and the Exclusion of Their African Origins. Publ. by 2002, Black Classic Press. Baltimor, MD 21203

Kendrick, J. 1850. Ancient Egypt under the Pharaohs. In two vol.B. Fellovs, London. Available at: https://ru.scribd.com/ document/115557076/Ancient-Egypt-Under-Pharaohs-I-Kendrick1850 (Accessed: 14.09.2018)

Lewis, H. S. 1929. (2015 Reprint). Mystical Life of Jesus. Martino Fine Books, 279 p.

Mathews, E.A. 1938. The Mediterranean World in Ancient Times. The Ronald Press Company, NY. Available at: https:// archive.org/details/in.ernet.dli.2015.166853/page/n7 (Accessed: 30.07.2018)

Muller, M. 1964. Mythology of Egypt. In: The Mythology of all races. Vol. XII Egyptian Indo-Chinese. Cooper Square Publishers. New York. Available at: https://archive.org/details/ egyptianmytholo00scotgoog/page/n102 (Accessed: 18.08.2018)

Nantambu, K. 2001. Ancient Egypt's Role in European History. Available at: http://www.africaspeaks.com/reasoning/ index.php?topic=1056.0; wap2 (Accessed: 11.08.2018)

Nantambu, K. 2004. Original Glory, not out of Greece. Available at: http://www.trinicenter.com/kwame/2004/2010.htm (Accessed: 12.08.2018)

NNDB. 2014. Pythagoras. Profile. Available at: http:// www.nndb.com/people/773/000087512/ (Accessed: 14.09.2018)

Obenga, T. 1995. A Lost Tradition: African Philosophy in World History, The Source Editions. Philadelphia, Pa.

Platt, D. 2001. Jesus as Fiction. Available at: http:// davidpratt.info/jesus.htm (Accessed: 19.09.2018)

Pliny (77-79 AD). Natural History. Vol 1-10. Transl. by H. Racham. Harvard Univ Pr; Loeb Library Edition edition (1967).

Roebuck, C. 1960. Ionian Trade and Colonization. Available at: https://www.jstor.org/stable/27682405?seq=1\#page_scan_tab_contents (Accessed: 22.09.2018).

Rogers, A.K. 1901. A Student's History of Philosophy. The Macmillan Co, NY-London.

Rosicrucian Digest. May, 1952. Published (May 23, 2010) by Kessinger Publishing, LLC. P. 175.

Shield, C. 2003. Ed. The Blackwell Guide to Ancient Philosophy. Oxford.

Silverman, D. P. 2003. Ancient Egypt. Oxford University Press. $256 \mathrm{p}$.

Stanley, T. 1655. History of Philosophy was originally published in 4 vols. London.

Stumpf, E. 1994. Philosophy: History \& Problems. McGrawHill, New York.

Clement of Alexandria. (150-215 AD). The Stromata. Available at: https://ethics ofsuicide.lib.utah.edu/s elections/clementalexandria/ (Accessed: 14.09.2018)

Turner, W. 1903. History of Philosophy. Ginn and Company, Publisher. Boston (USA)-London. Available at: https://archive.org/ details/historyphilosop00turngoog/page/n8 14.08.2018)

Vail, C.H. 1909. Ancient Mysteries and Modern Masonry. Available at: https://archive.org/stream/Ancient_Mysteries_And_Modern_Masonry_-_C_H_Vail/Ancient_Mysteries_And_Modern_Masonry_-_C_H_Vail_djvu.txt (Accessed: 05.08.2018)

Weor, S. 1956. The Major Mysteries. Available at: https:// gnosticteachings.org/books-by-samael-aun-weor/the-majormysteries/3615-jesus-in-egypt.html (Accessed: 02.08.2018)

Zeller, E. 1886. Outlines of History of Greek Philosophy. Longmans, Green Publ., London. Available at: https://archive.org/ details/outlinesofthehis00zelluoft/page/n9 (Accessed: 09.09.2018) 
Ебо Сократ,

доктор наук з соиіально-політичної філософії,

Інститут фундаментальних досліджень, Федеральний університет Отуоке, Баєлса, Нігерія

\section{ВІДНОВЛЕННЯ АФРИКАНСЬКОГО ПОХОДЖЕННЯ ФІЛОСОФІї}

У статті підіймається питання про генезу філософії. Метою статті є доведення африканських, зокрема єгипетських, джерел античної філософііі. Розповсюдженим стереотипом сучасності є те, що філософрія виникла в Мілеті, що підтверджується постаттю Фалеса, першої людини, яка начебто займалася формальною філософрією. Проте мало хто звертає увагу, що Фалес сам навчався філософії в Єгипті. Саме в Єгипті, під впливом Ефіопії, за тисячу років до Фалеса виникло та культивувалося раціональне ставлення людини до світу, яке отримало назву "себа" (мудрість), звідси - Софрія еллінів. Серед відомих філософів Стародавнього Єгипту були Тот, Аменхотеп, Імхотеп, Птахотеп, Аменехат, Мерікаре, Дуаф, Ехнатон. У Фівах (Люксорі) функціонував потужний інтелектуальний центр Васе, протоаналог європейських університетів, в якому навчалися Фалес, Анаксімандр, Піфагор, Сократ, Платон, Арістотель, Гіппократ, Евклід, Солон, Діодор, Евріпід, Архімед та інші. Те, що Піфагор назвав "філософією", насправді було "любов'ю до себи" (єгипетської мудрості) і в умовах Греції було контркультурою. Розповсюдження "себи" в Іонії, яка свого часу була провінцією Єгипту, сприяло проникненню ідей єгипетських мудреців до Європи. Грецькі філософи були лише популяризаторами вчення африканського походження.

У статті аналізуються особливості взаємодії еллінської та єгипетської культур. Називаються події, що призвели до занепаду і остаточного зникнення філософії в Єгипті, включаючи завоювання Александра Македонського, християнський вплив та поширення ісламу. Вказується на соціально-політичні причини, які в XIX столітті обумовили змову західних авторів щодо замовчування доказів африканського походження філософії та, навпаки, розповсюдження тези про "апильність африканського інтелекту" і принципову нездатність представників чорної раси до філософування. Автор закликає до відновлення історичної справедливості та визнання африканського пріоритету у виникненні філософрії.

Ключові слова: афрриканська фрілософрія; Єгипет; себа; Tот; Васе; антична фрілософрія; Іонія; Мілет; Фалес; Піфрагор; Арістотель.

\section{ЛІТЕРАТУРA}

Abdatista G. The Philosophy of Colonialism: Civilization, Christianity, and Commerce. 2011. URL: https://scholarblogs.emory.edu/ violenceinafrica/sample-page/the-philosophy-of-colonialism-civilization-christianity-and-commerce/ (Accessed: 25.09.18).

Alexander B. D. History of Philosophy. Glasgow, 1922.

Asante M. K. An African Origin of Philosophy: Myth or Reality?. 2004. URL: http://www.asante.net/articles/26/afrocentricity/ (Accessed: 11.09.18).

Aucher J. Philo, 1826

Ayo. The origins of the Ethiopian state. African House of Rastas. 2011. URL: https://www.africaresource.com/rasta/sesostris-thegreat-the-egyptian-hercules/the-origins-of-t he-ethiopian-state-by-prof-ayo/ (Accessed: 08.09.18).

BBC. 2014. URL: http://www.bbc.co.uk/history/historic_figures/pythagoras.shtml (Accessed: 08.09.18).

Bowder A. Nile Valley Contributions to Civilization. Washington, DC: Karmaic Institute, 1988.

Besant, A. Esoteric Christianity. Quest Books. 2nd edition (January 1, 2006), 302 p.

Flavio Josefo. Obras completas de Flavio Josefo, en 5 volúmenes traducidos del griego al español por Luis Farré. (Buenos Aires: Acervo Cultural / Editores, 1961.) Vol. 5: Contra Apión. URL: https://elmundobiblicodigital.files.wordpress.com/2013/12/contra-apic3b3nsobre-la-antiguedad-del-pueblo-judc3ado-por-flavio-josefo.pdf.

The Oxford Essential Guide to Egyptian Mythology / Eds.: Daniel R. McBride \& Berkley. Publisher: Berkley, 2003. 432 p.

Diogenes L. Lives of Eminent Philosophers. (c. 366 BC).

Diop C. A. The African Origin of Civilization, Myth or Reality? New York: L. Hill, 1974. 336 p.

Dunn J. (n.d). Amasis, the Last Great Egyptian Pharaoh. URL: http://www.touregypt.net/featurestories/amasis.htm (Accessed: 01.09.2018)

Frankfot H. Ancient Egyptian Religion. New York: Harper and Row, Harper torchbooks, 1948. 172 p.

Hasting. (1898-1904). Bible Dictionary. NY: C. Scribner's Sons (5 vols), 1963.

Hastings J. Encyclopedia of Religion and Ethics. 1908. URL: https://archive.org/details/encyclopaediaofr01 hastuoft/page/n9 (Accessed: 09.09.2018).

Herodotus. (450 BC). Histories. URL: http://classics.mit.edu/Herodotus/history.html (Accessed: 01.09.2018).

Jasnow R. L. \& Zauzich K.T. The Ancient Egyptian Book of Thoth: A Demotic Discourse on Knowledge \& Pendant to Classical Hermetica. Wiesbaden: Otto Harrassowitz Verlag, 2005. 678 p.

Jochannan Y. The Black Man's Religion. In: Vol.2 The Mith of Genesis is Exodus and the Exclusion of Their African Origins. Baltimor: Black Classic Press, 1974.

Kendrick J. Ancient Egypt under the Pharaohs. In two vol. B. Fellovs, London, 1850. URL: https://ru.scribd.com/document/115557076/ Ancient-Egypt-Under-Pharaohs-I-Kendrick-1850 (Accessed: 14.09.2018).

Lewis H. S. Mystical Life of Jesus. Martino Fine Books, 1929. (2015 Reprint). 279 p. 
Mathews E. A. The Mediterranean World in Ancient Times. NY.: The Ronald Press Company, 1938. URL: https://archive.org/details/ in.ernet.dli.2015.166853/page/n7 (Accessed: 30.07.2018).

Muller M. Mythology of Egypt. In: The Mythology of all races. Vol. XII Egyptian Indo-Chinese. New York: Cooper Square Publishers, 1964. URL: https://archive.org/details/egyptianmytholo00scotgoog/page/n102 (Accessed: 18.08.2018).

Nantambu K. Ancient Egypt's Role in European History. 2001. URL: http://www.africaspeaks.com/reasoning/index.php?topic$=1056.0$; wap2 (Accessed: 11.08.2018).

Nantambu K. Original Glory, not out of Greece. 2004. URL: http://www.trinicenter.com/kwame/2004/2010.htm (Accessed: 12.08.2018). NNDB. 2014. Pythagoras. Profile. URL: http://www.nndb.com/people/773/000087512/ (Accessed: 14.09.2018).

Obenga T. A Lost Tradition: African Philosophy in World History, Philadelphia, Pa: The Source Editions, 1995.

Platt D. Jesus as Fiction. 2001. URL: http://davidpratt.info/jesus.htm (Accessed: 19.09.2018).

Pliny (77-79 AD). Natural History. Vol 1-10 / Transl. by H. Racham. Harvard Univ Pr; Loeb Library Edition edition, 1967.

Roebuck C. Ionian Trade and Colonization. 1960. URL: https://www.jstor.org/stable/27682405?seq=1\#page_scan_tab_contents (Accessed: 22.09.2018).

Rogers A. K. A Student's History of Philosophy. NY-London: The Macmillan Co, 1901.

Rosicrucian Digest. May, 1952. Published (May 23, 2010) by Kessinger Publishing, LLC. P. 175.

The Blackwell Guide to Ancient Philosophy / Ed. C. Shield. Oxford, 2003.

Silverman D. P. Ancient Egypt. Oxford University Press, 2003. 256 p.

Stanley T. History of Philosophy was originally published in 4 vols. London, 1655.

Stumpf E. Philosophy: History \& Problems. New York: McGraw-Hill, 1994.

Clement of Alexandria. (150-215 AD). The Stromata. URL: https://ethicsofsuicide.lib.utah.edu/selections/clement-alexandria/ (Accessed: 14.09.2018).

Turner W. History of Philosophy. Boston (USA)-London: Ginn and Company, Publisher, 1903. URL: https://archive.org/details/ historyphilosop00turngoog/page/n8 (Accessed: 14.08.2018).

Vail C. H. Ancient Mysteries and Modern Masonry. 1909. URL: https://archive.org/stream/Ancient_Mysteries_And_Modern_Masonry__C_H_Vail/Ancient_Mysteries_And_Modern_Masonry_-_C_H_Vail_djvu.txt (Accessed: 05.08.2018).

Weor S. The Major Mysteries. 1956. URL: https://gnosticteachings.org/books-by-samael-aun-weor/the-major-mysteries/3615-jesusin-egypt.html (Accessed: 02.08.2018).

Zeller E. Outlines of History of Greek Philosophy. London: Longmans, Green Publ., 1886. URL: https://archive.org/details/ outlinesofthehis00zelluoft/page/n9 (Accessed: 09.09.2018).

(c) Ebo Socrates

Надійшла до редакції 08.10.2018 